\title{
Relevance of Dynamic Strain Aging under Quasi-Static Tension on AISI 304 Stainless Steel
}

\author{
Sergio Neves Monteiro *, Artur Camposo Pereira ${ }^{a}$, Fábio de Oliveira Braga $^{a}$, \\ Eduardo de Sousa Lima ${ }^{a}$, Carlos Luis Ferreira ${ }^{a}$
}

\begin{abstract}
aPrograma de Ciência dos Materiais, Instituto Militar de Engenharia - IME, Praça General Tibúrcio,
\end{abstract} 80, Urca, 22290-270, Rio de Janeiro, RJ, Brazil

Received: December 02, 2016; Revised: July 13, 2017; Accepted: September 04, 2017

The interval of existence of dynamic strain aging (DSA) in AISI type 304 austenitic stainless steel subjected to quasi-static tension tests, under strain rates from $3.5 \times 10^{-2}$ to $3.5 \times 10^{-4} \mathrm{~s}^{-1}$, in the temperature range from 25 to $800^{\circ} \mathrm{C}$ was investigated. It was found that DSA occurs in the range extending from around 200 to $700^{\circ} \mathrm{C}$. Plastic instabilities associated with serrations, Portevin-Chatelier effect, allowed activation energies to be calculated and a possible mechanism of dislocation interaction with interstitial carbon atoms to be proposed. Significant increase in the ultimate strength, uniform elongation and work hardening demonstrate that DSA is a relevant phenomenon, which improves the high temperature mechanical properties of 304 steel.

Keywords: Dynamic strain aging, austenitic stainless steel, work hardening.

\section{Introduction}

Dynamic strain aging (DSA) is a phenomenon first noticed by Stromeyer in $1885^{1}$ as a brittle cold-worked condition in common steel associated with a surface blue color, which was consequently named "blue brittleness". Later in 1909, André Le Chatelier ${ }^{2}$ reported, also in steel, an increase in tensile strength by varying the tensile test speed within the "blue brittleness" interval of temperatures. Not only steel, but other metals and alloys also present DSA. Indeed, a characteristic effect of plastic instability in the form of serrations was first indicated in aluminum by Albert Portevin and François Le Chatelier in $1923^{3}$. This has been referred as the "Portevin-Le Chatelier" effect, probably the most typical DSA manifestation. In addition to "blue brittleness", increase in tensile strength and serrations, DSA in steels was also found to cause peaks in the work hardening and inverse strains-rate dependence in the stress level ${ }^{4,5}$. All these DSA effects were explained by a mechanism of solute atoms interaction with moving dislocations generated during plastic deformation ${ }^{6-8}$. In particular, mainly interstitials solutes such as $\mathrm{C}$ and $\mathrm{N}$, are associated with a cloud of atoms, which became to be known as "Cottrell atmosphere", in honor to Alan Cottrell", first to explain the Portevin-Le Chatelier" phenomenon.

The DSA effects in common steels occurs in the interval from 50 to $300^{\circ} \mathrm{C}^{5}$, which is of limited practical interest since most standard carbon steels for automobile, house appliances and civil construction are normally used around room temperature. However, a special class of steels, the stainless, has extensively been applied at higher temperatures in engineering systems such as nuclear reactors, petrochemical equipments, boilers and gas turbines. Earlier works on

*e-mail: snevesmonteiro@gmail.com elevated temperature mechanical properties of stainless steels ${ }^{9-14}$ indicated the existence of maximum strength values in the range of 200 to $600^{\circ} \mathrm{C}$. This was attributed to DSA in the case of the austenitic stainless steel AISI (American Iron and Steel Institute) types $316^{10-12}$ and $304^{13,14}$. As for AISI type 304 austenitic stainless steels, short communications ${ }^{13,14}$ suggested the existence of work hardening stages that could be affected by DSA. However, it was not possible to determine activation energies associated with atomistic mechanisms. Recent works on 316 steel $^{15-18}$ related both anomalous variation in the work hardening parameters with strain rate and temperature as well as plastic instabilities and serrations with DSA.

The objective of the present work was to update information on AISI 304 austenitic stainless steel, since the high temperature DSA effects have not recently been investigated and characterization of mechanisms are still open to discussion. Therefore, the objective of this work was to evaluate the degree of relevance of DSA in the quasi-static (slow) strain rate tensile tested properties of a 304 steel from 25 to $800^{\circ} \mathrm{C}$.

\section{Experimental procedure}

The AISI type 304 austenitic stainless steel was supplied by Sandvik as rolled bars with $10 \mathrm{~mm}$ in diameter. The chemical composition of the basic elements in the steel is presented in Table 1.

In principle, 304 steel is not supposed to contain molybdenum. However, an electric furnace produced stainless steel from scrap may eventually present small percentage of non-specified elements such as Mo in Table 1. Standard ASTM tensile specimens machined with $4 \mathrm{~mm}$ of gage 
Table 1. Chemical composition of the AISI 304 steel.

\begin{tabular}{cccccccc}
\hline $\mathrm{C}$ & $\mathrm{Cr}$ & $\mathrm{Ni}$ & $\mathrm{Mo}$ & $\mathrm{Si}$ & $\mathrm{Mn}$ & $\mathrm{P}$ & $\mathrm{S}$ \\
\hline 0.05 & 18.8 & 8.5 & 0.47 & 0.57 & 1.67 & 0.024 & 0.015 \\
\hline
\end{tabular}

diameter and $24 \mathrm{~mm}$ of gage length were first annealed at $1100^{\circ} \mathrm{C}$ for one hour, and then electropolished to eliminate surface marks.

The annealed microstructure revealed equiaxed grain with $35 \mu \mathrm{m}$ in size. All specimens were vacuum tested in a model 1125 Instron screw driven machine at strain rates of $3.5 \times 10^{-2}, 3.5 \times 10^{-3}$ and $3.5 \times 10^{-4} \mathrm{~s}^{-1}$. Tests were carried out inside a tubular Instron furnace coupled to the machined at temperatures from $25^{\circ} \mathrm{C}$ (without furnace) up to $800^{\circ} \mathrm{C}$.

\section{Results and Discussion}

Figure 1 illustrates composed sequences of actual loadelongation curves, for tensile tests at strain rates of $3.5 \times 10^{-4} / \mathrm{s}$ and $3.5 \times 10^{-2} / \mathrm{s}$, directly obtained from Instron plotted graphs, for two strain rates. In this figure, only the plastic flow part of the curves is shown. It should be noticed that the $200^{\circ} \mathrm{C}$ curves for both strain rates is smooth, i.e. without plastic instabilities. In fact, from 25 up to $200^{\circ} \mathrm{C}$ all load-elongation curves are smooth and, for this reason, not shown in Fig. 1. Another relevant point is that non-uniform wavy plastic instabilities are observed above $200^{\circ} \mathrm{C}$ up to around $400^{\circ} \mathrm{C}$. Beyond this temperature, regular uniform serrations cover the curves. A close look at these higher temperature serrations reveals two distinct types. These are the well recognized ${ }^{19}$ types A (like "shark fins") and B (like "saw teeth"). One may notice that after the non-uniform instabilities (waves), finishing around $400^{\circ} \mathrm{C}$, type A serration starts and transform into type B at about $600^{\circ} \mathrm{C}$ going to an end at $700^{\circ} \mathrm{C}$.

Two important points deserve to be mentioned regarding the curves in Fig.1. First, both from the start and finish of instabilities/serrations it is concluded that quasi-static plastically deformed 304 steel undergoes DSA in the temperature interval from 200 to $700^{\circ} \mathrm{C}$, which is comparable to that of 316 steel $^{10-12,15,16}$. The reader should remember that the DSA interval, between 50 to $300^{\circ} \mathrm{C}$ for common carbon steel ${ }^{5}$, is significantly below the one here found for 304 steel, which coincides with applied high temperature conditions for stainless steels. Second, from the start and finish temperatures (T) for the different strain rates ( $\varepsilon$ ), an Arrhenius relationship can be considered:

$$
\dot{\varepsilon}=\dot{\varepsilon}_{0} \exp \left(-\frac{Q}{R T}\right)
$$

where $Q$ is the activation energy of the DSA mechanism and $\mathrm{R}$ the gas constant.

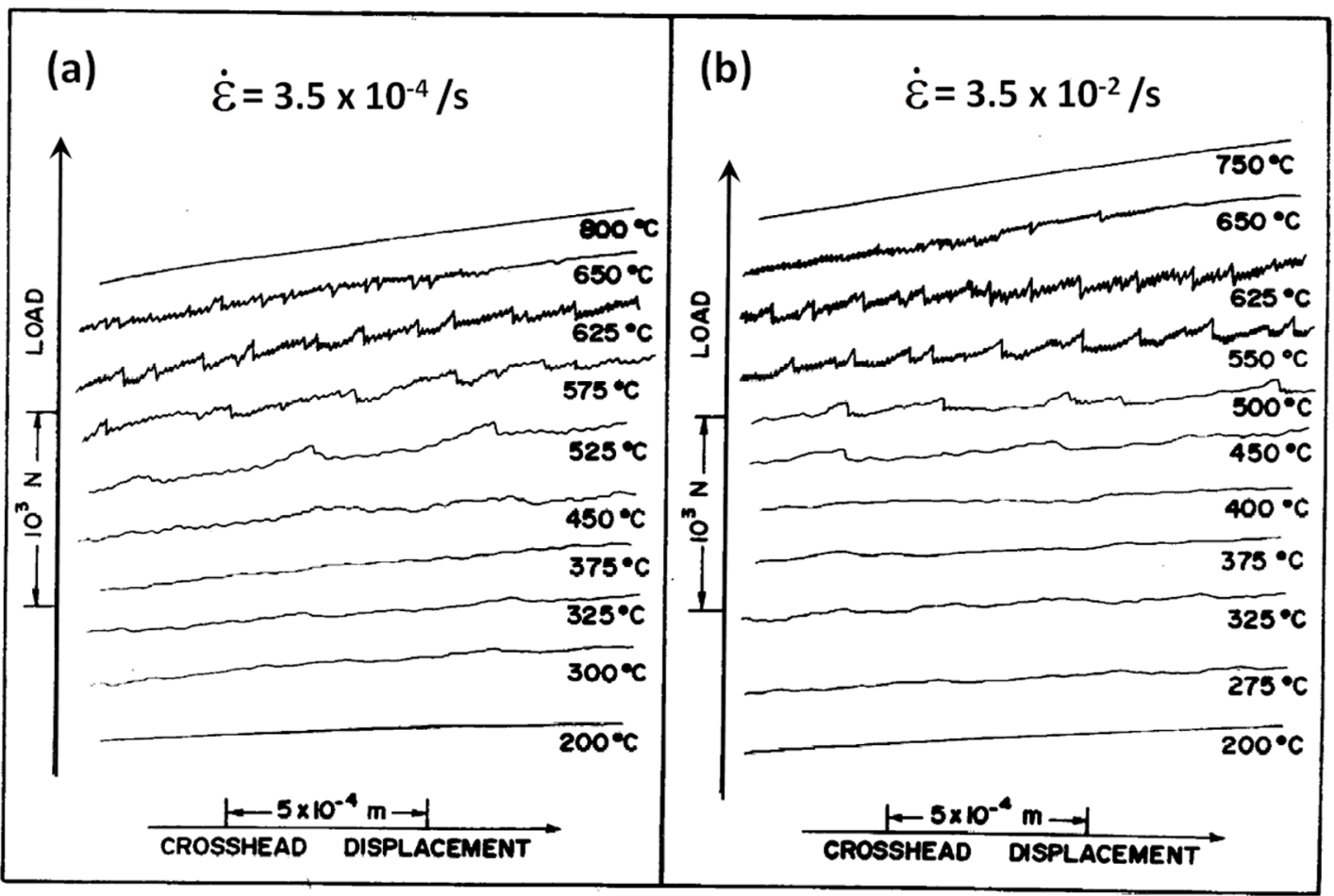

Figure 1. Partial load vs elongation flow curves for AISI 304 steel tensile tested at different strain rates: (a) $3.5 \times 10^{-4} \mathrm{~s}^{-1}$ and (b) $3.5 \times 10^{-2} \mathrm{~s}^{-1}$. 
Figure 2 shows the graphical representation of Eq. (1) for the start and finish of instabilities and types of serrations, from results illustrated in Fig.1.

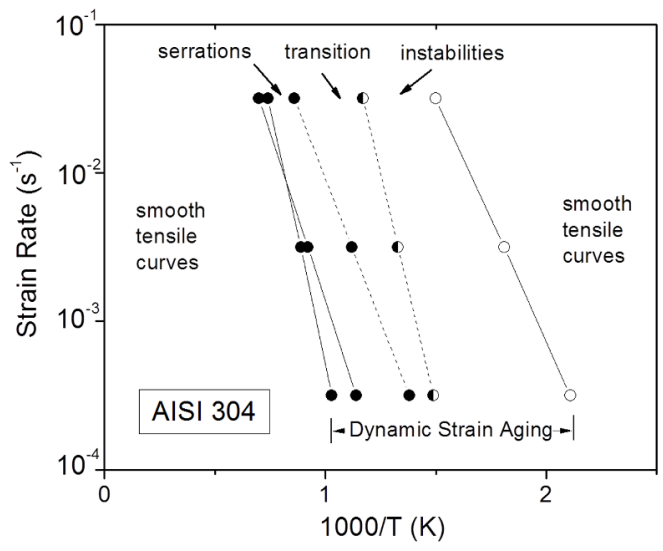

Figure 2. Variation of $\log \dot{\varepsilon}$ with $1 / \mathrm{T}$ for start and finish instabilities as well as serrations A and B in AISI 304 steel.

From the straight lines obtained in Fig. 2, activation energies for the mentioned start and finish results are listed in Table 2.

The upper values in Table 2, activation energies of 121 and $130 \mathrm{~kJ} / \mathrm{mol}$, might be assigned to the diffusion of $\mathrm{C}$ in $\gamma_{\mathrm{Fe}}\left(\right.$ face centered cubic - FCC - matrix), $148 \mathrm{~kJ} / \mathrm{mol}^{20}$. This can be interpreted as the mechanism of releasing the $\mathrm{C}$ atoms from the "Cottrell atmosphere" in association with the end of their interaction with dislocations, which causes DSA and serration in particular. The lower values $63-83 \mathrm{~kJ} / \mathrm{mol} \mathrm{might}$ be related to the binding energy of $\mathrm{C}$ to the dislocations at the beginning of "Cottrell atmosphere" formation ${ }^{5}$.

Having disclosed the temperature interval of DSA in 304 steel, its effects on the mechanical properties are now presented. Figure 3 shows the variation of the ultimate tensile strength with temperature for the three investigated strain rates. A dashed line is extended from the lower temperature $\left(25-200^{\circ} \mathrm{C}\right)$ values that are not affected by DSA to the higher temperature $\left(700^{\circ} \mathrm{C}\right)$ where DSA cease to exist. This allows the anomalous DSA increase in strength to be revealed between 200 and $700^{\circ} \mathrm{C}$.

Figure 4 shows the variation of the uniform strain with temperature for the three investigated strain rates. Different than common steels in which a minimum in strain, "blue brittleness", is associated with DSA ${ }^{4,5}$, the uniform strain in 304 steel is kept relatively constant around $25-35 \%$. This is a positive result, which indicates that 304 steel, contrary

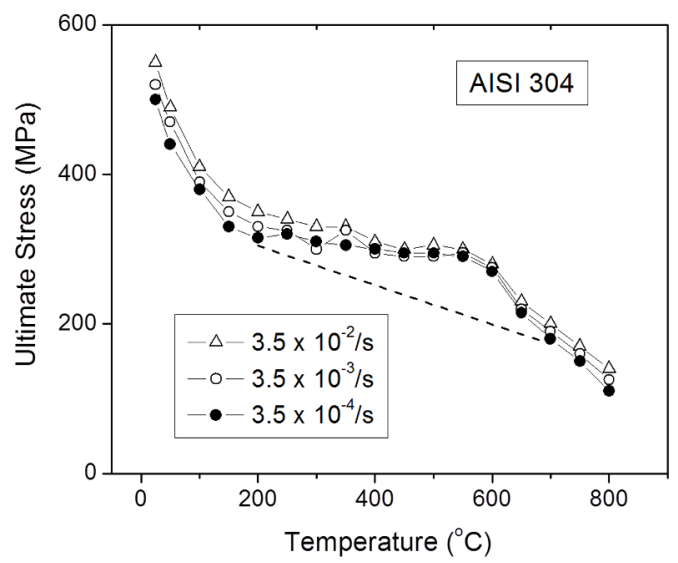

Figure 3. Temperature dependence of the ultimate tensile strength in AISI 304 steel.

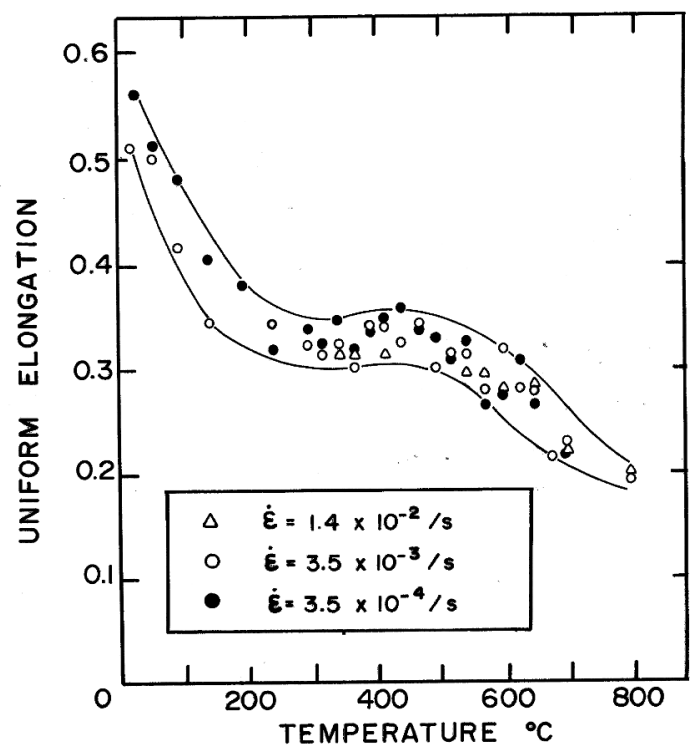

Figure 4. Temperature dependence of the uniform elongation in AISI 304 steel.

to common steel, does not suffer an embrittlement effect due to DSA.

Figure 5 shows the variation with temperature of the average work hardening rate $\Delta \sigma / \Delta \varepsilon$, between 0.5 and $5.0 \%$ of plastic strain, normalized for the elastic modulus E. A consistent tendency towards maximum values for each strain rate was found at three distinct regions: around 200$400^{\circ} \mathrm{C}$; from 400 to $550^{\circ} \mathrm{C}$ and from 550 to $700^{\circ} \mathrm{C}$. These work hardening peaks, within each region, were apparently shifted to higher temperatures with increasing strain rate.

Table 2. Activation energies for the start and finish instabilities as well as serrations A and B in AISI 304 steel.

\begin{tabular}{ccccc}
\hline \multicolumn{2}{c}{ Instabilities extending from $200-400^{\circ} \mathrm{C}$} & \multicolumn{3}{c}{ Serrations extending from $450-600-700^{\circ} \mathrm{C}$} \\
\hline Start & Finish & Start type A & A $\rightarrow$ B & Finish type B \\
$63 \mathrm{~kJ} / \mathrm{mol}$ & $121 \mathrm{~kJ} / \mathrm{mol}$ & $73 \mathrm{~kJ} / \mathrm{mol}$ & $88 \mathrm{~kJ} / \mathrm{mol}$ & $130 \mathrm{~kJ} / \mathrm{mol}$ \\
\hline
\end{tabular}




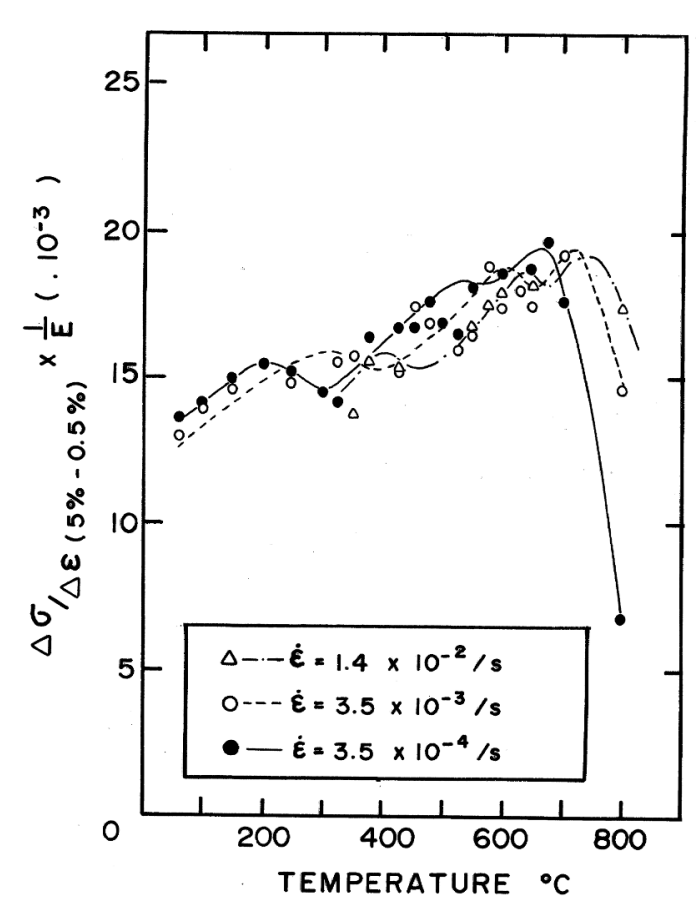

Figure 5. Temperature dependence of the average work hardening rate $\Delta \sigma / \Delta \varepsilon_{(0.5-5 \%)}$ normalized by the elastic modulus E in AISI 304 steel.

Table 3. Activation energies for the work hardening peaks in AISI 304 steel.

\begin{tabular}{lll}
\hline $200-400^{\circ} \mathrm{C}$ & $400-450^{\circ} \mathrm{C}$ & $550-700^{\circ} \mathrm{C}$ \\
\hline $120 \mathrm{~kJ} / \mathrm{mol}$ & $80 \mathrm{~kJ} / \mathrm{mol}$ & $160 \mathrm{~kJ} / \mathrm{mol}$ \\
\hline
\end{tabular}

Activation energies obtained from the Arrhenius equation for the shift of peak coordinates $(\dot{\varepsilon}, \mathrm{T})$ are presented in Table 3 .

One may notice that the ranges of work hardening peaks in Fig. 5 and Table 3 almost coincide with those of instabilities and serrations in Fig. 1 and Table 2. Moreover, the activation energy values associated with the work hardening peaks in Table 3 are comparable to those related to instabilities and serrations in Table 2. This confirms the mechanism of formation of "Cottrell atmosphere", beginning at $200^{\circ} \mathrm{C}$, and the $\mathrm{C}$ atoms release by first diffusion in the $\mathrm{FCC}$ matrix of 304 steel at $700^{\circ} \mathrm{C}$.

\section{Final Remarks}

The high temperature results from quasi-static tensile tests in 304 steel at different strain rates revealed relevant DSA effects, such as increase in strength, Fig. 3, and peaks in the work hardening, Fig. 5, that are beneficial to engineering applications. These effects are not as pronounced as in common steel $^{5}$ or titanium ${ }^{21}$. However, both (steel and Ti) present a deleterious minimum in ductility, which is not observed, Fig. 4, in 304 steel. This arises from the fact that the rate of hardening in 304 steel is kept high enough not to allow $\mathrm{d} \sigma / \mathrm{d} \varepsilon$ to be prematurely equal to $\sigma$, which is the
Considere's criterium ${ }^{22}$ for the onset of necking. As for the DSA mechanism in 304 steel, the activation energies shown in Tables 2 and 3 indicate that only interstitial $\mathrm{C}$ atoms, but no substitutional, like $\mathrm{Cr}$ or $\mathrm{Ni}$, is responsible for the interaction with dislocations. In addition, at the higher temperature interval of 550 to $700^{\circ} \mathrm{C}$ in Table 3 , DSA might also overlap with sensitization. This is a corrosion phenomenon, not necessarily under stress, which occurs in the range from 500 to $800^{\circ} \mathrm{C}$ by carbon diffusion to form $\mathrm{Cr}_{23} \mathrm{C}_{6}$ at grain boundaries ${ }^{20}$. One may then speculate that the release of carbon atoms from the "Cottrell atmosphere", responsible for DSA at the high temperature limit of DSA, promotes free carbon atoms with time long enough (low strain rates) to promote sensitization.

\section{Conclusions}

- Dynamic strain aging (DSA) was found to occur between 200 and $700^{\circ} \mathrm{C}$ in type AISI 304 austenitic stainless steel subjected to quasi-static tensile plastic deformation.

- Instabilities and serrations in the load-elongation curves permitted to evaluate activation energies that could be related to the formation of "Cottrell atmosphere" by the interaction of $\mathrm{C}$ atoms with dislocations.

- Anomalous increase in the tensile strength and peaks in the work hardening were characteristic DSA effects associated with relevant advantages for high temperature engineering applications of AISI 304 steel.

\section{Acknowledgements}

The authors thank the support to this investigation by the Brazilian agencies: CNPq, CAPES and FAPERJ.

\section{References}

1. Stromeyer CE. The injurious effect of a blue heat on iron and steel. Minutes of Proceedings of Institution of Civil Engineering. 1886;84:114-137.

2. Le Chatelier A. Influence du temps et de la température sur les essais au choc. Revue de Metallurgie. 1909;6(8):914-917.

3. Portevin A, Le Chatelier F. On a phenomenon observed in the tensile testing of alloys during processing (in French). Comptes Rendus de L'Academie des Sciences. 1923;176:507-510.

4. Baird JD. Strain-aging of steel - a critical review-part I: pratical aspects (cont). Iron and Steel. 1963;36:326-450.

5. Keh AS, Nakada Y, Leslie WC. Dynamic strain aging in iron and steel. In: Rosenfield AR, Hahn GT, Bement Jr. AL, Jaffee I, eds. Dislocation Dynamics. New York: McGraw-Hill; 1968. p. 381-405. 
6. Nabarro FRN. Deformation of crystals by the motion of single ions. In: Proceedings of the Conference on Strength of Solids. 1948; Bristol, UK. London: The Physical Society; 1948. p. 75-90.

7. Cottrell AH. LXXXVI. A note on the Portevin-Le Chatelier effect. Philosophical Magazine. 1953;44(355):829-832.

8. Baird JD. The effects of strain-aging due to interstitial solutes on the mechanical properties of metals. Metallurgical Reviews. 1971;16(1):1-18.

9. Simmons WF, Van Echo JA. Report on the elevated temperature properties of stainless steels, ASTM Data Series Publication DS-5-S1 (Supplement to Publication DS 5, formerly STP 124). Philadelphia: American Society for Testing Materials; 1965.

10. Conway JB, Berling JT, Stentz RH, Salyards DG. Stress strain behavior of several stainless steels to elevated temperatures. GEMP 686. Cincinnati: General Electric; 1969.

11. Michel DJ, Moteff J, Lovell AJ. Subestructure of type 316 stainless steel deformed in slow tension at temperatures between 21 and $816^{\circ}$ C. Acta Metallurgica. 1973;21(9):1269-1277.

12. Samuel EI, Choudhary BK, Rao KBS. Analysis of work hardening behavior of type $316 \mathrm{~L}(\mathrm{~N})$ austenitic stainless steel. Transactions of the Indian Institute of Metals. 2002;55:363-370.

13. Almeida LH, Monteiro SN, Kestembach HJ. On cell structure formation and work hardening stages in polycrystalline type 304 stainless steel. In: Proceedings of the Eleventh Annual Technical Meeting of the International Metallographic Society; $1978 \mathrm{Jul}$ 16-19; Montreal, Quebec, Canada. New York: Elsevier; 1979. p. 87-97.

14. Monteiro SN, Le May I, Almeida LH. Effects of strain rate and dynamic strain aging on work hardening of na austenitic stainless steel. Scripta Metallurgica. 1981;15(6):581-584.
15. Gupta AK, Singh SK, Reddy S, Hariharan G. Prediction of flow stress in dynamic strain aging regime of austenitic stainless steel 316 using artificial neural network. Materials \& Design. 2012;35:589-595.

16. Choudhary BK, Christopher J. Tensile flow and work hardening behavior of type $316 \mathrm{~L}(\mathrm{~N})$ stainless steel in the framework of one-internal-variable and two-internal-variable approaches. Materials Science and Engineering: A. 2015;636:269-278.

17. Christopher J, Choudhary BK. Kinetics of Uniaxial Tensile Flow and Work Hardening Behavior of Type 316 L(N) Austenitic Stainless Steel in the Framework of Two-Internal-Variable Approach. Metallurgical and Materials Transactions A. 2015;46(2):674-687.

18. Christopher J, Choudhary BK. On the assessment of tensile work hardening behavior of type $316 \mathrm{~L}(\mathrm{~N})$ austenitic stainless steel in the framework of $\theta \sigma \mathrm{d}$ vs. $\sigma \mathrm{d}$ using flow stress contribution from dislocations. International Journal of Pressure Vessels and Piping. 2016;146:151-160.

19. Brindley BJ, Worthington PJ. Yield-point phenomena in substitutional alloys. Metallurgical Reviews. 1970;15(1):101114 .

20. Callister WD Jr., Rethwisch DG. Materials Science and Engineering - An Introduction. $8^{\text {th }}$ ed. Hoboken: John Wiley \& Sons; 2009.

21. Garde AM, Santhanam AT, Reed-Hill RE. The significance of dynamic strain aging in titanium. Acta Metallurgica. 1972;20(2):215-220.

22. Meyers MA, Chawla KK. Mechanical Behavior of Materials. $2^{\text {nd }}$ ed. New York: Cambridge University Press; 2008. 